\title{
Instrument of Improvement or Degradation: Contemporary University Rankings and Their Problems
}

\author{
Sergiy Kurbatov
}

$\mathrm{PhD}$, affiliated researcher at Uppsala University (Sweden); Head of the Department of Leadership and Institutional Development, Institute of Higher Education of the National Academy of Sciences of Ukraine.

\begin{abstract}
The paper is devoted to the analyses of current situation in the area of theory and methodology of university rankings. The author identifies three main problems in this area. First of all, it is the problem of relation of measurable and non-measurable dimensions of university activities and the relevant limitation of possibility to use ranking as the universal technology of evaluation. Secondly, it is the relations between objective and subjective data in elaboration of relevant indicators. Thirdly, is the problem of necessity of exclusive and authentic methodology for university ranking or possibility to apply universal methodology. The results of main international and Ukrainian university rankings in 2017 are also presented.
\end{abstract}

Key words: university, university rankings, methodology, indicators, learning outcomes, objective and subjective data

JEL Classification: I23, C1.

(C) The Author, 2017. This article is published with open access at ARMG Publishing.

\section{Introduction}

The author of an analytical article that appeared in the British newspaper The Guardian on August 21, 2017 Andre Spicer gives impressive statistics. In particular, between 1975 and 2008, the number of managers at American universities increased by $221 \%$, while the number of teachers increased by only $10 \%$. Two thirds of British universities currently have more managers than teachers. Although 50\% of the adult population has higher education, only $20 \%$ of the workforce needs it. While studying at a university, $46 \%$ of students do not demonstrate improvement in their own cognitive abilities. And, finally, the number of local entrants to British universities dropped this year by 4\% (Spicer, Andre, 2017). Professor of John Hopkins University (USA) Benjamin Ginsberg in 2011 stated the emergence of an "all-administrative university" based on the fact that university management actively concentrates power in its own hands and keeps off its lecturers and researchers, which results in an increasing bureaucratic regulation of all aspects of university life, limitation of academic freedoms and university corporatization (Ginsberg, Benjamin, 2011).

On the other hand, the rapid development of information and communication technologies opens impressive alternatives for obtaining modern knowledge, in particular in the form of massive open online courses (MOOC), the example of which in Ukraine is the Prometeus Platform (About the project Prometeus) created in 2014. This platform offers the best courses from the teachers of Taras Shevchenko National University of Kyiv, National Technical University of Ukraine "Igor Sikorsky Kyiv Polytechnic Institute" (KPI) and National University of "Kyiv-Mohyla Academy" free of charge. The Coursera platform (Coursera), created in 2012, provides free access to courses of professors from the best universities in the world.

Therefore, the contemporary university, despite the almost thousand-year history that embodies the sustainability of this social institution, seems to be in a deep crisis. However, we could not speak about the Harvard or Princeton crisis, which endowments continue to grow year after year together with the growth of education prices and varied indicators of academic achievements. For example, the endowment of Harvard from 2005 to 2015 grew from \$ 25.9 billion to \$ 37.6 billion (Harvard University Endowment). How to evaluate the effectiveness of university activities and the expediency of using taxpayers' funds to hold a particular institution of higher education? How to understand, whether the declared price of educational services corresponds to the quality of the received "product"? Universities of which countries in the situation of the active formation of the global educational area are already or are trying to be the leaders, and who falls behind? University rankings can give answers to these and many other questions asked by applicants and their parents, students, employers, government officials and education experts.

The aim of this article is to analyze the key problems which face the developers of university rankings. In our time, rankings have become one of the most popular mechanisms for evaluating the quality of university 
education that is understandable and accessible to all stakeholders. But how far is this mechanism able to cover all the dimensions of the university activity and how to minimize the negative impact of rankings on the academic environment now? We will try to analyze these issues in our paper.

\section{Literature review and discussion}

"If rankings did not exist, someone would sooner or later invent them, because the emergence of rankings is a logical result of the mass character of higher education, as well as the commercialization and competition of universities around the world", mentioned in 2011 American researcher Philip Altbach (Altbach, Philip G., 2011: 2). That is, the ratings allow us to build a certain hierarchy of institutions of higher education in conditions of massification both at the national and global levels. So, only in Ukraine, according to the State Statistics Service of Ukraine, the number of higher education institutions of the 3rd and 4th accreditation levels has increased from 149 in 1990-1991 academic year to 287 in 2016-2017 academic year (State Statistics Service of Ukraine). They provide an opportunity to assess the appropriateness of public and private investment in educational projects, and also help loudly announce themselves to strong players in the higher education market, primarily through the media, which were at the root of university ratings and traditionally show a high interest to them. "The emergence of global classifications and university rankings galvanized the world of higher education. Universities can not avoid national and global comparisons with the emergence of global university rankings, and this fact leads to a change in many university functions", emphasizes Andrejs Rauhvargers (Rauhvargers, A., 2011: 68).

This comparison process is often unpleasant, painful and dramatic, because recognized national "kings" of the academic world often turn out to be practically "naked" at the regional and global levels. This idea is perfectly formulated by Simon Marginson: "At the time when nations perceive themselves in the context of global competition, and global comparisons are becoming an important element in many areas, university rankings occupy a corresponding niche. They make the secret and complex world of universities simple, transparent and understandable" (Marginson, Simon, 2014: 45). Indeed, on a wave of secularization, the university paradoxically "intercepted" the church's peculiar ability to be the object of sacred projections, becoming such a "temple of science". And to measure sacred is sacrilege. As one of the main founders of the nineteenthcentury theoretical discourse, John Henry Newman, wrote with pathos about the university: "This is the place which fame attracts young people, which touches the feelings of the middle-aged people and, through communication, wins the friendship of older people. This is the home of wisdom, the light of the world, the messenger of faith, the alma mater of the young generation" (Newman, John, 2002: 44).

What is the basis of this ranking ability to disavow the sacral dimension peculiar for the university through centuries? The ranking is based on the principle of comparing universities and educational programmes on the ground of predefined parameters or complex indicators that reflect the key components of university training. Among these components, the educational process, research activity and internationalization play the dominant role at the present stage. Of course, developers of rankings are guided by the parameters that can be measured.

\section{Results}

And here we face the first fundamental problem that is associated with the spread of university rankings - the problem of the ratio of measurable and non-measurable parameters of university activity. By the way, the latter have played and continue to play an important role in university life, and pathos of John Henry Newman is appealing right to them. Formation of intellectual culture and outlook, sense of self-worth and patriotism are just those humanitarian aspects of university activity that are difficult and sometimes impossible to measure but which largely determine the basis for the existence of a university as a social institution. And without these aspects, the existence of the university as a social institution would be lost, and replaced by various trainings, corporate training programmes, online courses, etc. By the way, the Spanish philosopher José Ortega y Gasset wrote in 1930 about the danger of minimizing the humanitarian component of university education and noted that "modern university was over-complicated by vocational education, and further the research study was added, which almost completely displaced the study and transfer of culture" (Ortega y Gasset, José, 2002: 76). At the same time, the transfer of culture is the first component of university education along with learning and research (Ortega y Gasset, José, 2002: 80). That is, rankings should take into account that there are fundamentally important areas of university life that can not be measured, and therefore make no pretense to being universal. As a derivative of this problem there can be attempts to indirectly measure why it is difficult to find objective digital equivalent, for example, learning outcomes. A detailed analysis of this problem can be found in the article "The problem of measuring learning outcomes and improving existing university ranking systems" (Kurbatov, Sergiy, 2017). 
Rankings are a relatively young tool for evaluating the quality of university education, since the first national university ranking was published in 1983 in the American Journal US News \& World Report and continues to be in our time (Best Global Universities Rankings), and the first international university ranking appeared only in 2003 thanks to the work of Chinese experts from the Shanghai University, called the Academic Ranking of World Universities (ARWU) or Shanghai Ranking. Of course, the authors of the first university rankings were guided by the parameters that are in open databases and easily measured. The methodology of this ranking over 15 years of existence has not undergone significant changes and has a steady character (Ranking Methodology of ARWU). Nowadays, this ranking estimates more than 1,300 universities, the top five of which have individual positions, and universities that occupy positions from 501 to 800 are identified as candidates to enter the ranking (Ranking Methodology of ARWU). Shanghai Ranking can be conventionally called the ranking of the Nobel Prize laureates and other prestigious academic awards, as the presence of such laureates among university lecturers and graduates is one of the key indicators of this ranking. Accordingly, it evaluates mainly research activity and practically ignores the learning process, and is based only on objective data. Unfortunately, Ukrainian universities are not included in this ranking, but in the general database of Shanghai Ranking there are three national universities - Taras Shevchenko National University of Kyiv, V.N. Karazin Kharkiv National University and Sumy State University.

Another way was chosen by the authors of the Time-QS Ranking, which was first published in 2004, and since 2010 it has been titled QS World University Rankings. The methodology of this ranking is also sustainable and has not undergone significant changes during its existence (QS World University Rankings: Methodology). Along with objective parameters such as the citation index of scientific papers, the ratio of teachers and students, the number of foreign students and teachers, they also use the subjective data obtained as a result of a global survey of experts in the field of higher education and employers. The problem of interrelation between objective and subjective data is the second fundamental problem that faces the developers of university rankings. By the way, it is precisely because of subjective data we can, though quite indirectly, evaluate the humanitarian component of university activity. Unlike Shanghai Ranking, Ukrainian universities are represented in the QS Ranking, for example, Vasyl Karazin KhNU in 2018 is in the latest version of the ranking in the category 401-410, Taras Shevchenko National University of Kyiv is in the category 411-420, National Technical University of Ukraine "Igor Sikorsky KPI" is in the category 501-550, National Technical University "KhPI" is in the category 701-750, Sumy State University and Vasyl Stus Donetsk National University are in the category 801-1000.

Also, in 2004, the Webometrics Ranking of World Universities, which evaluates the University's presence on the Internet and the important parameters of its site (Webometrics Methodology), appeared. According to the results of the latest July version of this ranking for 2017, Taras Shevchenko National University of Kyiv takes the first place in Ukraine, and, at the same time, takes only the 1299th position in the world, National Technical University of Ukraine "KPI" takes the second place (the 1685th position in the world), Sumy State University takes the third place (the 2112th position in the world).

An attempt to develop a more complicated and multidimensional ranking based on the combination of objective and subjective data can be considered to be the appearance of THE World University Rankings or New Times Ranking in 2010. Unlike Shanghai Ranking and QS Ranking, the methodology of this ranking is quite dynamic. The latest version of this ranking includes 12 indicators and covers such components of university activities as training, research activity, citation index of scientific papers, level of internationalization and profit from cooperation with industry and transfer of knowledge (World University Ranking 2018 Methodology). Among the thousand of the best universities in the world according to TNE in 2018, we can find only Taras Shevchenko National University of Kyiv (category 801-1000). The emergence of this ranking, as well as of the U-Multirank developed in 2014, which methodology includes a large number of indicators, has intensified the discussion about the specifics of the university ranking methodology, which is the basis for the third fundamental problem that experts are trying to solve - whether the rankings should have their own methodology, or they should rely on the methodology, while existing within the framework of modern social sciences. For example, Simon Marginson believes that the existing methodological toolkit of social sciences should be the basis for the development of university rankings (Marginson, Simon, 2014).

I tried to make a consolidated table of five of the best world universities according to the four leading international university rankings (ARWU, QS, THE and Webometrics) - in a similar way to the compilers of the Consolidated ranking of higher educational institutions of Ukraine. For this purpose, the positions that the leading universities take in the respective rankings have been summarized. As a result, the University Academic Olympus in 2017 is shown in Table 1: 
Table 1. Consolidated ranking of the best world universities in 2017

\begin{tabular}{|c|l|c|c|c|c|c|c|}
\hline No. & University & Country & ARWU & QS & THE & Webometrics & Total \\
\hline 1 & Stanford & USA & 2 & 3 & 3 & 1 & 9 \\
\hline 2 & Harvard & USA & 1 & 2 & 6 & 2 & 11 \\
\hline 3 & MIT & USA & 4 & 1 & 5 & 3 & 13 \\
\hline 4 & Cambridge & UK & 3 & 5 & 2 & 10 & 20 \\
\hline 5 & Oxford & UK & 7 & 6 & 1 & 7 & 21 \\
\hline
\end{tabular}

The first national ranking of the Ukrainian universities was the "Sofia Kyivska" ranking, which appeared in 2000. Currently, the most professional domestic ranking is TOP 200 Ukraine, which was started in 2007. In the latest version of this ranking for 2017 Sumy State University takes the honorable 11th position among domestic universities. A dozen of the best Ukrainian universities is presented in Table 2 (University ranking TOP 200 Ukraine, 2017):

Table 2. The best Ukrainian universities according to the results of the ranking TOP 200 Ukraine in 2017

\begin{tabular}{|c|c|c|c|c|c|}
\hline No. & University & $\begin{array}{l}\text { Quality assessment of } \\
\text { scientific and } \\
\text { pedagogical potential }\end{array}$ & $\begin{array}{l}\text { Education } \\
\text { quality } \\
\text { assessment }\end{array}$ & $\begin{array}{l}\text { Assessment of } \\
\text { international } \\
\text { recognition }\end{array}$ & $\begin{array}{l}\text { Assessment of } \\
\text { integral activity } \\
\text { indicator }\end{array}$ \\
\hline 1. & $\begin{array}{l}\text { National Technical University of } \\
\text { Ukraine "Igor Sikorsky Kyiv } \\
\text { Polytechnic Institute" }\end{array}$ & 37.418142 & 24.281419 & 24.4829 & 86.182459 \\
\hline 2. & $\begin{array}{l}\text { Taras Shevchenko National } \\
\text { University of Kyiv }\end{array}$ & 37.769754 & 20.839431 & 23.28319 & 81.892371 \\
\hline 3. & $\begin{array}{l}\text { Vasyl Karazin Kharkiv National } \\
\text { University }\end{array}$ & 19.751908 & 14.676816 & 15.06279 & 49.491519 \\
\hline 4. & $\begin{array}{l}\text { National Technical University } \\
\text { "Kharkiv Polytechnic Institute" }\end{array}$ & 18.573207 & 10.14642 & 16.38257 & 45.10219 \\
\hline 5. & $\begin{array}{l}\text { Lviv Polytechnic National } \\
\text { University }\end{array}$ & 12.008843 & 15.626166 & 17.03906 & 44.674071 \\
\hline 6. & National Mining University & 21.093455 & 10.546152 & 12.75355 & 44.393153 \\
\hline 7. & $\begin{array}{l}\text { Bogomolets National Medical } \\
\text { University }\end{array}$ & 28.103072 & 7.6483286 & 8.041441 & 43.792842 \\
\hline 8. & $\begin{array}{l}\text { National University of Life and } \\
\text { Environmental Sciences of } \\
\text { Ukraine }\end{array}$ & 17.665546 & 14.957859 & 10.36397 & 42.987377 \\
\hline 9. & $\begin{array}{l}\text { Ivan Franko National University } \\
\text { of Lviv }\end{array}$ & 12.020464 & 14.703774 & 16.07945 & 42.803691 \\
\hline 10. & $\begin{array}{l}\text { Kyiv National Economics } \\
\text { University named after Vadym } \\
\text { Hetman }\end{array}$ & 11.894025 & 18.473218 & 11.72613 & 42.09337 \\
\hline
\end{tabular}

An interesting domestic project is the beforementioned Consolidated ranking of higher educational institutions of Ukraine, which is calculated on the basis of the positions that universities rank in TOP 200 Ukraine (University ranking TOP 200 Ukraine, 2017), Webometrics (Ranking Web of Universities) and the index of citations in database SCOPUS. The top ten Ukrainian universities in 2017 is shown in Table 3:

Table 3. The best Ukrainian universities according to the Consolidated ranking of higher educational institutions of Ukraine in 2017

\begin{tabular}{|c|l|c|c|c|c|}
\hline No. & \multicolumn{1}{|c|}{ University } & TOP 200 & Webometrics & Scopus & Total \\
\hline 1. & Taras Shevchenko National University of Kyiv & 2 & 1 & 1 & 4 \\
\hline $2-3$. & $\begin{array}{l}\text { National Technical University of Ukraine "Igor Sikorsky Kyiv } \\
\text { Polytechnic Institute }\end{array}$ & 1 & 2 & 6 & 9 \\
\hline $2-3$. & Vasyl Karazin Kharkiv National University & 3 & 4 & 2 & 9 \\
\hline 4. & Ivan Franko National University of Lviv & 9 & 5 & 4 & 18 \\
\hline 5. & National Technical University "Kharkiv Polytechnic Institute" & 4 & 7 & 9 & 20 \\
\hline 6. & Lviv Polytechnic National University & 5 & 8 & 10 & 23 \\
\hline 7. & Sumy State University & 11 & 3 & 13 & 27 \\
\hline 8. & Odessa I.I. Mechnikov National University & 17 & 6 & 5 & 28 \\
\hline 9. & Yuriy Fedkovych Chernivtsi National University & 24 & 12 & 3 & 39 \\
\hline 10. & $\begin{array}{l}\text { National University of Life and Environmental Sciences of } \\
\text { Ukraine }\end{array}$ & 8 & 11 & 25 & 44 \\
\hline
\end{tabular}




\section{Conclusions}

Consequently, it can be stated that the process of developing the theory and methodology of university rankings is now undergoing an active phase and is in the focus of interest of both managers and experts in the field of higher education and various groups of consumers of educational services in Ukraine as well as other countries of the world. At the present stage, we can identify three fundamental problems in this area. First, it is the problem of relation of measurable and non-measurable dimensions of university activities and the relevant limitation of possibility to use ranking as the universal technology of evaluation. Secondly, it is a problem of the ratio of objective and subjective data to fill the indicators in the process of developing university rankings. Finally, thirdly, it is the problem of the appropriateness of the exclusive and authentic methodology for the development of university rankings.

\section{References}

1. About the project Prometeus. URL: https://prometheus.org.ua/about-us/.

2. About U-Multirank. URL: http://www.umultirank.org/\#!/about?trackType=about\&sightMode=undefined.

3. Academic Ranking of World Universities. URL: http://www.shanghairanking.com/ARWU2017.html.

4. Altbach, Philip, G. (2011). Rankings Season Is Here / Philip G. Altbach // International Higher Education, $62,2-5$.

5. Best Global Universities Rankings. URL: https://www.usnews.com/education/best-globaluniversities/rankings.

6. Consolidated ranking of HEIs of Ukraine (2017). URL: http://osvita.ua/vnz/rating/51741/.

7. Coursera. URL: https://www.coursera.org/.

8. Harvard University Endowment. URL: https://en.wikipedia.org/wiki/Harvard_University_endowment.

9. Ginsberg, Benjamin (2011). The Fall of the Faculty. The Rise of All-Administrative University and Why Its Matters. Oxford University Press, 264 P.

10.Kurbatov, Sergiy (2017). Problema vymiryuvannya rezul'tativ navchannya $i$ vdoskonalennya isnuyuchykh system universytet:s'kykh reytynhiv [The problem of measuring learning outcomes and improving existing university ranking systems]. Higher education of Ukraine, 2, 18-22.

11. Marginson, Simon (2014). University Rankings and Social Science. European Journal of Education, 49(1), $45-59$.

12.Newman, John (2002). The idea of the University: Anthology, pp. 37-64.

13. Ortega y Gasset, José (2002). Mission of the University. Anthology, pp. 67-107.

14.QS World University Rankings. URL: https://www.topuniversities.com/qs-world-university-rankings.

15.QS World University Rankings: Methodology URL: https://www.topuniversities.com/qs-world-universityrankings/methodology.

16.Ranking Methodology of ARWU. URL: http://www.shanghairanking.com/ARWU-Methodology2017.html.

17.Ranking Web of Universities. URL: http://www.webometrics.info/en.

18. Rauhvargers, A. (2011) Global university rankings and their impact. URL: http://www.eua.be/pubs/Global University Rankings and Their Impact.pdf.

19.SCOPUS. URL: https://www.elsevier.com/solutions/scopus.

20.Spicer, Andre (2017). Universities are broke. So let's cut the pointless admin and get back to teaching. URL: https://www.theguardian.com/commentisfree/2017/aug/21/universities-broke-cut-pointless-adminteaching.

21. State Statistics Service of Ukraine. URL: http://www.ukrstat.gov.ua/.

22.THE World University Rankings. URL: https://www.timeshighereducation.com/world-universityrankings/2018/world-ranking\#!/page/0/length/25/sort_by/rank/sort_order/asc/cols/scores.

23.U-Multirank. URL: http://www.umultirank.org/.

24.University ranking TOP 200 Ukraine (2017). URL: http://osvita.ua/vnz/rating/55849/.

25.Webometrics Methodology. URL: http://www.webometrics.info/en/Methodology.

26.World University Ranking 2018 Methodology URL: https://www.timeshighereducation.com/worlduniversity-rankings/methodology-world-university-rankings-2018. 